\title{
Études/Inuit/Studies
}

\section{Language, identities and ideologies of the past and present} Chukotka

\section{Langue, identité et idéologie en Tchoukotka autrefois et aujourd'hui}

Daria Morgounova

Volume 31, numéro 1-2, 2007

\section{Tchoukotka}

Chukotka

URI : https://id.erudit.org/iderudit/019721ar

DOI : https://doi.org/10.7202/019721ar

\section{Aller au sommaire du numéro}

\section{Éditeur(s)}

Association Inuksiutiit Katimajiit Inc.

Centre interuniversitaire d'études et de recherches autochtones (CIÉRA)

\section{ISSN}

0701-1008 (imprimé)

1708-5268 (numérique)

Découvrir la revue

Citer cet article

Morgounova, D. (2007). Language, identities and ideologies of the past and present Chukotka. Études/Inuit/Studies, 31(1-2), 183-200.

https://doi.org/10.7202/019721ar

\section{Résumé de l'article}

L'histoire de la Tchoukotka est celle d'un contact intensif et de rapides changements sociopolitiques, économiques, culturels et spirituels, ce qui rend souvent difficile toute prédiction, y compris en ce qui concerne la langue. Lors de ma première visite en Tchoukotka en 2003, le sentiment de la conscience ethnique des Yupiget était très fort. La majorité de la population yupik exprimait une attitude positive envers sa langue autochtone et on pourrait y voir une tendance vers sa revitalisation. Pourtant, lorsque je suis revenue en 2005 j'ai constaté un changement de statut de la langue yupik et de sa notoriété. Dans cet article j'aborde le changement de situation linguistique en Tchoukotka en comparaison avec l'île Saint-Laurent, en Alaska. Je fais la lumière sur ce rapide changement de langue constaté durant mon travail de terrain dans cette région en 2003 et 2005. Je présente des explications possibles sur la courte durée du mouvement de revitalisation dont j'ai été témoin au début d'un nouveau millénaire et qui avait déjà pris fin en 2005. 


\section{Language, identities and ideologies of the past and present Chukotka}

\section{Daria Morgounova*}

Résumé: Langue, identité et idéologie en Tchoukotka autrefois et aujourd'hui

L'histoire de la Tchoukotka est celle d'un contact intensif et de rapides changements sociopolitiques, économiques, culturels et spirituels, ce qui rend souvent difficile toute prédiction, y compris en ce qui concerne la langue. Lors de ma première visite en Tchoukotka en 2003, le sentiment de la conscience ethnique des Yupiget était très fort. La majorité de la population yupik exprimait une attitude positive envers sa langue autochtone et on pourrait y voir une tendance vers sa revitalisation. Pourtant, lorsque je suis revenue en 2005 j'ai constaté un changement de statut de la langue yupik et de sa notoriété. Dans cet article j'aborde le changement de situation linguistique en Tchoukotka en comparaison avec l'île Saint-Laurent, en Alaska. Je fais la lumière sur ce rapide changement de langue constaté durant mon travail de terrain dans cette région en 2003 et 2005 . Je présente des explications possibles sur la courte durée du mouvement de revitalisation dont j'ai été témoin au début d'un nouveau millénaire et qui avait déjà pris fin en 2005.

Abstract: Language, identities and ideologies of the past and present Chukotka

The historical background of Chukotka is one of intensive language contact and of rapid socio-political, economic, cultural and spiritual change, which often makes any predictions difficult, also in regard to language. When I first came to Chukotka in 2003, the Yupiget sense of ethnic awareness was very strong. The majority of the Yupik population expressed positive attitudes towards their Native language and seemed to be supportive of its revitalisation. However, when I returned to Chukotka in 2005, I found out that the Yupik language status and loyalty had shifted. In this paper, I discuss language shift in Chukotka with reference to St. Lawrence Island, Alaska. I also cast light on language transformations and adaptation that I have documented during my fieldwork in the area in 2003 and 2005, and give possible explanations as to why the revitalisation movement that I witnessed in the beginning of the new millennium was short-lived and had ceased by 2005 .

Department for Cross-Cultural and Regional Studies, University of Copenhagen, Leifsgade 33, DK2300 Copenhagen, Denmark.daria@hum.ku.dk 


\section{Introduction}

Altogether, the Bering Sea realm is home to roughly 2,000 Yupik ${ }^{1}$ people. Initially, they were one people; they spoke the same language and had the same cultural orientation which took its roots in an ancient lifestyle of marine mammal hunting (Kerttula 2000: 136). The political separation of the communities officially took place in 1867, when the Russians sold Alaska to the United States. Yet having been ignored by colonisers for at least another 50 years, in practical terms, the separation did not occur until the Soviet government established control over the Chukotkan territory in the late 1920s. In 1945-1946 the international border was closed, and for the next 40 years all movement across the border was prohibited. These years of complete isolation finally ended in 1988 with an initiation of extensive exchange programs and more or less regular visits between members of the communities throughout the 1990s.

Today, the Yupik people inhabit two distinct geographical and political areas with the majority of the Yupiget living in four villages. Two of the villages, Gambell and Savoonga, are situated on St. Lawrence Island, which since 1867 has been officially a part of the United States of America. Two other villages, Novoe Chaplino and Sireniki, form a part of the Provideniya District, one of the existing eight administrative areas of the Chukotka Autonomous Region in the Russian Far North. In 2004, 816 Yupiget were registered here: 322 in the village of Novoe Chaplino, 272 in Sireniki and 182 in the town of Provideniya. Approximately half of the residents in the two villages are Yupik, while only about $6 \%$ of the population of the town of Provideniya is Yupik. Smaller Yupik communities are also registered in the villages of Nunligran, Yanrakynnot, Enmelen (District of Provideniya), Uel'kal' (District of Iultin) and the city of Anadyr ${ }^{2}$. The density of the Yupik population of Alaska is much higher. According to the 2000 United States Census, the population of St. Lawrence Island alone was 1,292 persons (643 in Savoonga and 649 in Gambell), over 95\% of which were Yupik people ${ }^{3}$. A population distribution similar to that in Chukotka can be found in more urban areas of Alaska, such as Nome and Anchorage.

The majority of the Yupik people that inhabit the Chukchi Peninsula belong to a linguistic group called Central Siberian Yupik (CSY), also known as Chaplino Yupik Eskimo in Chukotka, after the village of (Novoe) Chaplino. The St. Lawrence Island (SLI) Yupik Eskimo language is believed to be an offspring of the Chaplino Yupik language and, apart from a few phonetic, phonological, morphological, syntactical and lexical peculiarities, is practically identical to it (Krauss 1980: 46-47; de Reuse 1994: 5; Vakhtin and Golovko 1987: 7). This linguistic similarity is often attributed to emigration from Chukotka to St. Lawrence Island. The population of St. Lawrence

The plural of Yupik is Yupiget. Yupik people should not be confused with the Central Alaskan Yup'ik (plural Yupiit) group that inhabits the Alaska Peninsula and counts over 20,000 people.

These data were provided partly by the Administration of the Provideniya District and partly by the Native NGO called Yupik. The number of Yupik population given by the Russian Federation Census 2002 is 1534 (see www.raipon.org). The official census makes no difference between various groups, so the number cited includes speakers of Chaplino Yupik Eskimo and Naukan Yupik Eskimo.

3 See www.masterliness.com/a/Savoonga.Alaksa.htm, www.masterliness.com/a/Gambell.Alaska.htm. 
Island was once estimated at 4,000 people living in 35 villages, but it was greatly reduced by famine and plague in 1878-1879. Afterwards, the island was repopulated by Yupiget from Chukotka whose significant immigration to St. Lawrence Island continued until the late 1920s (Krauss 1980: 10-11, 46) ${ }^{4}$.

Today, CSY is one of the world's four remaining Yupik Eskimo languages. Together with Central Alaskan Yup'ik (10,000 speakers), Alutiiq (400) and Naukan (75), CSY forms the Yupik branch of the Eskimo-Aleut language family (Krauss 1997: 32-33; de Reuse 1994: 5) . Out of four Eskimo languages, i.e. Chaplino, Naukan, Sireriki Yupik ${ }^{6}$, and Big Diomede Inupiaq, registered within the Soviet borders in the 1930s (Menovschikov 1980; Robert-Lamblin 1993), Chaplino and Naukan Yupik are the two remaining Eskimo languages today. However, the number of Yupik speakers has markedly declined over the past century. The number of speakers in Chukotka, by their own account, is no more than 300, while on St. Lawrence Island, the Yupik language (though declining in use) is still spoken by the majority of the adult population.

The political separation of the Yupik people and their following integration into the modern world signalled a major turn in the development of the communities. While interaction between the split Yupik people throughout the major part of the 20th century has been limited, their contact with colonisers, Americans and Russians on each side respectively, has been intense, shaping their way of life, their culture and their languages. This paper discusses linguistic transformations and adaptations that have taken place in Chukotka in the recent years. It demonstrates how a changing pattern of ethnic self-identification has influenced the native population's uses of minority- and majority-associated languages, and argues that the Yupiget's selfascription as a group (and as individuals) and their use of language(s) in the research communities is interrelated and dominated by a changing relationship of the Yupik people with other ethnic groups and with the St. Lawrence Island Yupiget. The data presented here are findings from my fieldwork in Chukotka in March-April 2003 and September-October 2005, and in the village of Gambell, St. Lawrence Island in JulyAugust 2007.

\section{The Soviet linguistic ideology}

The present linguistic situation in Chukotka is linked to the socio-economical, political and ideological changes in the region. It was determined by the Soviet national ideology imposed on people during more than 50 years of Soviet administrative policy

\footnotetext{
4

On the Yupiget contribution to Alaskan population recoveries, see Krupnik (1994: 49-80).

5 All Eskimo languages fall into two main subgroups: Inuit-Inupiaq and Yupik, though many now believe that Sireniki formed a third entity ( $c f$. Fortescue in this issue). Inuit-Inupiaq is spoken in Greenland, the Canadian Arctic and Northern Alaska. The Yupik languages are spoken on the shores of the Chukchi Peninsula in the Russian Far East and in Alaska (Comrie 1981: 254; Woodbury 1984: 49).

6 On the extinction of the Sireniki Yupik Eskimo Language see Krupnik (1991).
} 
and "by a painful transformation [...] of the previous system" (Vakhtin and Krupnik 1999: 3). The Soviet impact on the "Numerically Small Peoples of the North" in general, and the Yupik population of Chukotka in particular, is well-described and leaves no doubt that it affected most, if not all, aspects of their life (e.g., Comrie 1981; Diment and Slezkine 1993; Krupnik 1993; Vakhtin 1992).

It is significant to point out that the conceptual foundation for the Soviet Union was Lenin's theory of "good ('oppressed-nation') nationalism" (Slezkine 1994: 414), a political ideology that "had an all-country scope to build a new 'socialist' nation of formerly exploited non-Russian 'working masses', each with a written language and literate communist bureaucracy of its own" (Krupnik 1992: 192). According to this belief, all nations ${ }^{7}$ (or ethnic groups) were equal because they had the same rights or at least should be given equal rights. Among other things, they had the equal right to possess a Native language, a culture, and a territory. However, the ethnic groups were not equal in their size, in their development, and in their economic and moral qualities (Slezkine 1994: 416-420). In fact, they were subordinate to the "Great Russians." In the colonisation of Chukotka, Russians were assigned "the status of "vanguard of modernisation' and of the bearers of 'advanced' forms of ideology and culture" (Krupnik and Vakhtin 2002: 17). This allowed the Russian-speaking outsiders to colonise the area in large numbers ${ }^{8}$ and to create a kind of hierarchy where they placed themselves above the Native people, politically as well as culturally, exposing them to constant mockery (Golovko et al. 2004: 75).

The belief in the ascribed nature of ethnic identity, Russian superiority, and primitive nature of Native peoples was reinforced by Stalin's view on the "nationality question." By Stalin's formulation, ethnicity 9 was considered a lower level as compared to Soviet citizenship and hence equalled backwardness. Stalin wanted to eliminate the economic, political and cultural "backwardness" of ethnic groups to allow them to catch up with central Russia" (Slezkine 1994: 435).

This dominating policy had several serious outcomes. First, it resulted in the formation of ethnic regions that were mapped by the State in accordance with a "one nation, one language" principle. Language was chosen as the main criterion for defining ethnic groups, and all territorial groups that were considered by ethnographers and linguists to be speaking dialects of the same language were defined as one ethnic group. This grouping was often done without taking into consideration how these groups actually defined themselves and hence had nothing to do with the people's own self-ascription (Golovko et al. 2004; Gray 2005). One linguistic variety was then

A nation was "a historically evolved stable community of language, territory, economic life, a psychological make-up manifested in a community of culture" (Slezkine 1994: 416-420).

In 20 years (1955-1975), the population of Chukotka was doubled from 70,000 to 150,000 people; by the end of the 1970s, new settlers (mainly Russian-speaking) constituted more than half of the total population of the region (Krupnik 1993: 24; Vakhtin 1992: 18, 1997: 165-166)

9 The term "nationality" was used with the meaning of "ethnicity," yet "no one bothered with distinction between nations and nationalities, least Stalin himself. The dictatorship of proletariat consisted of countless national groups (languages, cultures, institutions)" (Slezkine 1994: 433). 
chosen as an official standard for each ethnic group, "regardless of local tribal and dialectal distances" (Krupnik 1992: 195). This forced the Yupik population, where the Chaplino Yupik language was chosen as an official standard, to "adopt one of their existing dialects as a base to build their new identity and educational system" (ibid.: 196). Secondly, I believe that the imposed ideology was a strong factor in the formation of a new Soviet identity that, as it is emphasized by Slezkine (1994), came to be associated with Russian culture, literature and language. According to Stalin, Russian was by definition Native, and hence was proclaimed by official propaganda, while ethnic languages and cultures were discouraged (ibid.: 450).

Finally, as a result of this extreme influx of a Russian-speaking population and policies of forceful relocation in the second half of the Soviet dominance, the population of Chukotka became extremely ethnically mixed. In what had been previously their exclusive territory, the Yupik people found themselves a tiny minority among other ethnic groups and Russian-speaking outsiders (Comrie 1981: 35; Krupnik 1993: 24). As Comrie (1981: 36) writes, "In mixed groups of this kind, Russian inevitably becomes the lingua franca", and "even if one wants to maintain its Native language, he will find it increasingly permeated by Russian vocabulary items." Indeed, by the end of the 1980s, Russian was the lingua franca of the whole area, the Yupik language had borrowed more than 300 words from it and there were almost none, or very few, of the children on the mainland that grew up speaking Yupik (Vakhtin 1997). Hence, the situation in Chukotka could be described as a cultural and linguistic assimilation with language shift being almost complete.

\section{Late Soviet and post-Soviet transformation}

During the past 15-20 years, however, the Yupik people have been dragged into the turmoil of political, economic, spiritual and cultural changes that shaped their perception of their traditional culture, identity, and Native language. The process of glasnost and the softening of formerly tight bureaucratic control have stimulated political and economic activism in Chukotka (Gray 2005; Vakhtin and Krupnik 1999: 29). It has opened the area for international research, thereby increasing the interest towards Native cultures and languages from outside and forcing the Native population to challenge the established ethnic boundaries (Kerttula 2000; Vakhtin and Krupnik 1999: 33).

At the same time, the demise of the Soviet Union had plunged the whole country into a socio-economic and ideological crisis. A rapid depopulation of the area (within 15 years, the population of Chukotka decreased from 163,934 in 1989 to 51,410 in $2004^{10}$ ), extreme poverty and, finally, famine in 1999-2000 put the old Soviet values and existing ethnic boundaries into question (Kerttula 2000) and strengthened the Yupik culture and ethnicity internally. Apart from overall growing cost of living, bankruptcy and unemployment, the Native population was also suffering from hunger, 
increased suicide, critical shortage of medical and professional care, shortage of electricity, hot water, etc. As it was often mentioned by my informants, the only way to survive during this time was by going back to the traditional way of living. In 1999, Vakhtin and Krupnik (1999: 34) wrote: "The spiritual vacuum which the collapsed ideology of communism left behind demands a replacement." It is therefore only logical to suppose that "the sudden demise of Soviet values triggered a growing interest in ethnic roots, religion, alternative spiritual values, and new identities" (ibid.: 33).

The need for "reinvention of tradition" 11 was additionally reinforced by various exchange programs and visits between the Yupik population of Chukotka and SLI after the reopening of the Russian-American border in 1988. These visits were numerous throughout the 1990s; they dispelled the existing image of the West created during the Soviet times and allowed the Yupik population of Chukotka to establish close bonds with the islanders. For the Yupiget of Chukotka in particular, their relation to Alaska became of extreme importance during this period. Alaska became a kind of saviour, not only by means of financial support, but also spiritually: the Yupiget of Chukotka were not alone! Access to material resources now could be achieved by acquiring a Yupik identity. Since the Yupik language on St. Lawrence Island was very strong at that time, access to Yupik identity could be achieved through the Yupik language. The Yupik language hence became the most explicit marker of ethnic identity. According to Vakhtin and Krupnik's (1999: 28) research in Chukotka in 1995-96, there was "the growing concern in survival and continuity of the Indigenous tradition" and the majority of the Yupik population was rather "enthusiastic about studying Native languages, history, crafts, and subsistence skills at school" (ibid.: 34).

\section{Language usage and alternation in Chukotka in 2003}

In March-April 2003, I conducted two months of fieldwork in Chukotka, in the village of Novoe Chaplino. The purpose of the fieldwork was to investigate the use of the Native language among the Yupik population in the area by means of qualitative (interviews and observations) methods. In addition, 64 questionnaires comprising 75\% of all school children in the village between the age of 10 and 17 were collected. The children were asked if they spoke the Native language and if they used Native words in their Russian speech, and then, asked to give a few examples of known Yupik words and Yupik-Russian mixed sentences.

Similar to the 1995-1996 findings, described in Vakhtin and Krupnik's (1999) article, the research showed that the population was actively involved in social and traditional activities in the village. There was a very strong sense of ethnic identity among the Yupik population. The Yupik language was considered to be an essential marker of that identity and as several of my Yupik informants underlined: "Speaking the Yupik language is a matter of pride for every Yupik in Chukotka." Those that did

i i The term is used by Krupnik and Vakhtin (2002: 30) with reference to Hobsbawm and Ranger (1983). 
not speak the Native language were often identified by the speakers of the language as being less Yupik.

Despite the fact that Russian was the dominant language in the village, intensive code-switching and mixing ${ }^{12}$ (insertion of CSY words into Russian and incorporation of Russian roots into the Yupik language structure) were quite common. Today, only people over 40 in Chukotka are bilingual, therefore Russian-Yupik code-switching was mostly restricted to the Yupik population over 40. Often, the speakers of the language would switch into Yupik when they wanted to hide something from a child or an outsider, when approaching an elder, when telling a joke or a story, or in order to emphasise a greeting, warning, surprise or disappointment, e.g., the use of particles keka (ouch, hot!) and saa (to denote "I don't know"). In the case of emphasis, a sentence would often start with Yupik, followed by a switch into Russian.

Children whose knowledge of Yupik was very poor (if any) had a tendency towards the incorporation of single Yupik words or chunks of speech into their Russian speech. This was most often done for satirical marking or mocking, e.g., paraphrasing the way the elders talk. One of the teachers told me that the incorporation of Yupik words into a Russian text was also often used during Yupik classes, as in the following example:

$$
\begin{aligned}
& \text { Motrosskii nasaperaq tapghaaghaq } \mathrm{v} \text { ruke, } \\
& \text { Nesu ya angyaghpak po bystroi reke } \\
& \text { I skachut wamen'gu za mnoi po pyatam } \\
& \text { I prosyat menya: "Prokati kapitan"13 }
\end{aligned}
$$

A tendency, previously described by several researchers (de Reuse 1994; Vakhtin 1985), is intense code-mixing (insertion of CSY roots into Russian):

CSY Chaplinski: Ja eto niive-ayu? - '(Do) I pour it out?' (Vakhtin 1985: 43)

This tendency is also present in SLI Yupik. Yet, since the majority of children on St. Lawrence Island in the 1980s were Yupik-dominant, the insertion occurred in the other direction, in particular, from English into Yupik:

CSY SLI (1994): Around and around-engllaghnaqunga - 'I am going to make circles (while drawing)' (de Reuse 1994: 305).

12 Code-switching is "the alternate use of two languages in the same utterance or conversation" common for bilingual speakers (Grosjean 1982: 145, 150). The distinction between code-switching and codemixing is a contextual one: code-switching is "where an alternation between languages or a preference for one language or another with a meaning discernable through sequencing," and code-mixing (the community's code) is "where there is no such alternation or preference in the community" (Auer 1990, 1998, discussed in Clyne 2003: 71 ).

13 English translation (English equivalents for the Yupik words are underlined):

A sailor's hat, a rope in the hand,

I carry a steamer down the streams of the river?

And frogs are jumping, chasing my steps

And ask me, "Give me a ride captain." 
Today, however, with the majority of the SLI children being dominant in English, the insertion occurs in the same direction as in the first example. One of the most common uses is adding the present continuous ending -ing to the Yupik stem:

CSY SLI (2007): $\quad$ He is nengagh-ing -'He is leaving because he is angry'

Note that code-switching and code-mixing is different from lexical borrowing in that the switched element is not integrated into the other language:

CSY SLI - English:

Who made your taquq -'Who made your hair?/Who braid your hair?' Can you amaq(e-) me too? -'Can you lift me up and carry too?'14

CSY Chaplinski - Russian:

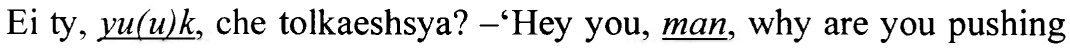
me?'

Aqume na stul-'(You) sit down on the chair'

Kakie-to laluramkiit priekhali -'Some white people have arrived'

Yet, as it is pointed by Grosjean (1982: 145-146), "code-switching is meaningful in much the same way that lexical choice is meaningful." Hence, code-switching into a minority language, as shown in the above cases, can signal in-group solidarity becoming an ethnic identity marker.

Another interesting tendency among the Yupik population of the Russian Far North, which pointed towards a growing prestige of the Yupik language, was the use of Russian roots within Yupik word and sentence structures in an attempt to say something in Yupik, especially by those who were not proficient at Yupik. For example:

1) Awivaghten podmeta-ghnaqunga-'Move further away, I will sweep out' (incorporation of a Russian verb /podmetat'/ 'to sweep')

2) Maketen, igaghvigmun opozda-ghllequten - 'Get up! You(1) are going to be late to school' (incorporation of a Russian verb /opozdat'/ 'to be late')

Such 'attempts' were often met with laughter by those more versed in Yupik. A seemingly similar example is:

3) Whanga wha shkola-mun pinaqunga -'Yet, I have to go to school' (incorporation of a Russian noun /škola/ 'school')

Yet, while in the first two examples, the borrowed-from-Russian verb stem stands in place of a missing Yupik stem (an ad hoc substitution) the word shkola (school) in

14 The verb amaqe- means 'to carry on one's back'. In a majority of the cases of English-Yupik mixture, the word was usually used with the meaning 'lift me up and carry.' 
the last example is not an ad hoc substitution for a missing Yupik word, but a Russian loan ${ }^{15}$. Note that during Soviet times, the Yupik language has borrowed over 300 words from Russian, including a large part of the socio-political vocabulary, words connected with military service, transportation, economic activities and experiences such as work in schools, clubs, cinemas, radio, television, post office, etc ${ }^{16}$. The newly introduced objects and concepts were usually borrowed directly from Russian and adapted to the derivational or syntactic patterns of Yupik, e.g., /gerb sovetskogo sojuza/ has been borrowed from Russian into Yupik as sovetskim sojusim gerbinga, 'the Emblem of the Soviet Union' (Vakhtin and Yemelyanova 1988: 215) or as in the above example with school (shkola-mun). The Yupik word for school is igaghvik (a writing place) as shown in example 2. In the recent years very few Russian loanwords have entered CSY, mostly through the Russian mass media. These are often connected with new world events, for example, war in Iraq, new political streams like /lévye/ 'left wing', /právye/ 'right wing,' /sotsialdemokráty/ 'social democrats.' Another example is: Voyna taana Irag-me yeqayngan naangyagh-tugh-li-quq ('This war in Iraq will not again make the ending/will probably not come to an end quickly').

The growing prestige and accelerated use of the Yupik language and RussianYupik alternation in Chukotka was typically attributed to communication across Bering Strait, particularly with the Yupiget of St. Lawrence Island. When the RussianAmerican border was opened the majority of the Chukotkan Natives did not know the English language at all. So, they were trying to recover what was left of the Yupik language in order to communicate with their neighbours. As a result, not only did people develop positive attitudes towards their Native language, but they also attempted to learn it. Several of the people I had talked to claimed to have learned the language after the reopening of the border because of their visits to Nome and St. Lawrence Island.

The Chaplino and Naukan Yupik speakers whom I interviewed in 2003 often mentioned that the young people's attitude towards Yupik has become more positive in recent years. According to them, their knowledge of the Native language, though limited, has been expanding, primarily due to their visits to Alaska. Thus, a teacher of the Yupik language that I interviewed in 2003 said: "During the past 10 years our young people began to respect the language more and tried to study it, because what if you will go somewhere, visit Alaska for example [...] the most important thing is to know the (Yupik) language." However, the majority agreed that the children's knowledge decreased as they returned home, mostly because of the lack of a linguistic environment in the village.

The questionnaire research showed that almost all the children (with the exception of four) claimed to have knowledge of the Native language and they claimed to speak it to some extent. No one claimed to be fluent in the language, but three considered their knowledge of the language to be quite good. The majority of the children admitted to

\footnotetext{
15

16

The word appeared in Yupik printed texts as early as 1947, and later in 1949 and 1951 publications.

A list of CSY socio-political terminology is given in Vakhtin and Yemelyanova (1988: 214-220).
} 
be using Yupik words and phrases when they spoke Russian and were able to give examples of such use. The examples given by children in their questionnaires were most often related to traditional way of life and occupation and included words such as angyaq ('skin boat'), angtughpaq ('walrus bull'), mangtak ('skin of a whale'), nungightaa ('to tie a boot'), nunivak (a very popular edible plant, can also mean 'tundra'), qikmiq ('dog'), qiku ('clay,' used for seal oil lamps), quvegsi (Polyonum tripterosarpum, a food plant), tunuq ('reindeer'), uupa ('sea peach').

One of the often mentioned explanations by the Yupiget to such a limited use of the Native language today was a considerable gap between the older generation and the young ones. In contrast to the older generation, almost no parents (people between the age of 20 and 40) spoke Yupik, and they were therefore unable to pass the language on to their children. The use of Yupik by young parents seemed to be restricted to short commands such as "be careful!", "attention!", "let's go", and short phrases where Yupik words were incorporated into Russian, e.g., Alquutak dai (Give me the spoon), or Dai mne uunghaq (Give me the harpoon tip). Some of the older school children I have talked to claimed to have spoken Yupik with their grandparents. One 16-year old Yupik boy told me that when he was a child he was fluent in Yupik, and when I asked him why he doesn't speak the language today he simply answered "Granny died." Indeed, this was a common case, very similar to the one I observed in the village of Gambell in 2007: the young people and children that were fluent in the language were those that grew up with their grandparents.

Another reason often mentioned by the Yupik population was the lack of the necessary educational system. The educational system provided little (if any) support for the learning and preservation of the Yupik language (Vakhtin 1992: 31). Moreover, in recent years the educational system has paid more attention to the English language. According to the teachers at the secondary school in the village of Novoe Chaplino, there was an increasing interest in the English language especially among teenagers. Not only did they (especially those who have been in Alaska) find it amusing to use some English words in their speech, but they often "confused" English with Yupik when trying to speak one or another language. This can be related to the increasing bilingualism and Yupik-English mixing on St. Lawrence Island. While the older generation was picking up Yupik, the younger ones were learning English along with Yupik.

On the whole, it was obvious that even though Yupik use in the area was limited, the Yupiget's' attitudes towards their Native language were very positive. The status and prestige of the Yupik language also seemed to have expanded, and there were quite a few uses of the language in the village. I was therefore interested in exploring if the documented language uses in the region were a sign of a possible "revitalisation" of the Yupik language. 


\section{The decline}

In 2005, however, only two and a half years later, I found the situation in Chukotka stunningly different. To a large degree, I was using the same methods as before. I was trying to engage new participants as well as to talk with my old informants. The questionnaire was extended to a 10 pages survey and included a much broader spectrum of questions regarding language use and attitude. The change, however, was obvious. The socio-cultural life of the village was in decline. Elderly, School, and Women's Councils, that had been active and had taken care of social problems in the village in 2003 were invisible, or non-existent in practice. There were continuing reductions in the numbers of whale hunters ${ }^{17}$; dancing and singing practices; and traditional arts and craft-making. The latter forms of traditional culture were promoted during the Soviet times, but now were limited to tourist visits to Chukotka; Yupik visits of Alaska; various exhibitions; feasts; and competitions.

Together with a decline of the socio-cultural activities in the village, the Yupik language status and loyalty had also shifted. The majority of my informants considered the knowledge of their Native language to be unnecessary and unpractical in everyday life, which resulted in a lack of motivation to learn the language. When I asked a 12year old Yupik boy which language he spoke with his friends, he replied "of course Russian! What else? Surely not Eskimo", and when I asked "Why not?" he sarcastically replied "who ever wants to speak that language?!" In 2005, this was without a doubt the attitude of the majority of the Native and non-Native Chukotkan populations. The non-Native people in particular, often called my attention to the unwillingness of the Native population to learn their languages.

Together with the changing attitudes of the Yupik population, the use of the Yupik language in the area has also decreased. In comparison to an intensive Russian-Yupik code-switching and mixing in 2003, I registered very few cases of code-switching in 2005. Rarely did I hear it during phone conversations (in most cases, in order to hide what the conversation was about, almost immediately followed by a switch into Russian). Code-switching was also used during the Yupik language classes at school and in kindergarten, usually in the form of stories, poems, songs, and short elementary conversations. Yet, school instruction in the village was exclusively in Russian, and since 2003, the amount of Yupik hours has been reduced (cancelled in grades 9-11) in favour of English. The school principal of the Novoe Chaplino School attributed it to the introduction of the Russian president V. Putin's Edinyi Gosudarstvennyi Eksamen ('Unified State Exam') which made English an obligatory subject to be passed when entering any higher educational institution.

A few examples of the use of the Yupik language, often mentioned by my informants, were related to place names and traditional activities, in particular sea

17 There are two reasons for that: 1) the number of whaling brigades and hunters is constantly reduced by administration/whaling commission that is still the only employee, and 2) men can earn more money by working at e.g., electric power plants or as construction-workers. 
mammal hunting. Nevertheless, although words like unraq/uunghaq ('harpoon tip'), ayveq ('walrus'), angtughpak ('walrus bull'), etc. were perceived by the Yupik population as markers of their ethnic identity and even children seemed to know them, they were seldom used in practice. For instance, during my four days stay with hunters in one of their whaling bases, almost no Yupik words were used in any of the situations. Place names, in turn, were still used by all natives. A 20 -year old man told me: "But of course we do [speak Yupik]. We use place names only in Yupik."

Another example of language use that I witnessed in the village of Novoe Chaplino was storytelling. At the time of my work in the village, several Yupik women under the leadership of Lyudmila Makotrik initiated a club called Pagitak ('An Inheritance'). The aim of the club was to talk in the Yupik language. The women gathered two or three times a week to talk in Yupik about culture, traditions, food, and to record the knowledge shared by the elders. Every time they would invite an elder that would tell a story in Yupik. According to my knowledge, the club existed for several months before it was temporary closed due to the health problems of its head initiator. The last time I spoke with inhabitants of the village of Novoe Chaplino in August 2007, the club was not yet reopened.

Hence, the general picture in 2005 was almost the opposite of the observations made by Vakhtin and Krupnik (1999) in 1995-96 and of my own findings in 2003. Mainly, as we have seen, throughout the 1990s and at the time of my first fieldwork in the area, there was a high sense of ethnic awareness among the Yupik people, they expressed positive attitudes towards their language, were conscious about its loss and were trying to use more Yupik in their everyday life. In 2005, however, the sense of ethnic identity of the Yupik population of the Russian Far East was rather weak, there was a generally negative attitude towards the Native languages, and I found very few uses of Yupik in practice. The question then is what caused the increase (if there was one) in the use of the Yupik language by the Yupik population in the first place, and why have their loyalty to and uses of their language ceased by 2005 ?

\section{Explaining the shift: Where has the language gone?}

One more event needs mentioning in order for us to complete the ethnohistory of the region and to answer the above question. On December $24^{\text {th }}, 2000$, the Russian billionaire R.A. Abramovich was elected as the governor of Chukotka (reappointed in 2005) and a sudden flow of money into the region has once again overturned the lives of the Chukotkan people. During the first couple of years, the economic crisis in the region was practically terminated. Indeed, when I arrived to the village of Novoe Chaplino in 2005, the economy of the village had improved, 64 new houses (an addition to the 46 houses built in-between 2001-2003) were built. Salaries, child allowances and pensions were paid regularly, and there was a steady supply of goods into the village, just to mention a few of the changes. 
The ethno-political activism, as it is mentioned elsewhere, had already ceased in most parts of the region by the mid 1990s, as a result of the "we are all (Russians and Native peoples) in this together!" administrative policy, initiated by Chukotka's previous governor (Gray 2005: 49). In the new millennium, this policy continued, though differently, under governor Abramovich. In the recent years, it was additionally inflated by President Putin's "exploitation of nostalgia of Soviet times"18. As a result, instead of a fostering continuously on traditional culture and language shift, people were reaching out for the old Soviet values, and the region was experiencing a kind of "reversed nationalism-in-question." In-question because there was "an apparent drift from ethnicity to territoriality" where, as it was predicted by Krupnik and Vakhtin (2002) the cultural heritage was "transformed into a marker of 'Chukotkan identity' for both the Native and non-Native populations" (ibid.: 34). Thus, for the vast majority of the Yupik people I talked to in 2005, the question of one's "belonging" was no longer defined by ethnicity, but rather, it was related to specific places, commitments and experiences. For the elderly population, it was often their birth settlement or at least the myths about it, which they were still trying to pass to the young ones through storytelling. For the younger population, it was more the question of being a citizen of Chukotka or Russia. Thus, in a 2005 survey, when asked "Do you first of all consider yourself ...?" the kids were given the following possibilities: Russian, Eskimo ${ }^{19}$, Chukchi, citizen of Chukotka, and citizen of Russia. The majority would underline the last two choices, citizen of Chukotka or citizen of Russia. When I later asked one of my young informants why he would choose this answer, he told me: "First of all I am a Russian citizen, and then Eskimo." Hence,

One's "home" was indeed the place of one's birth, the area where one lived as a child, got married or simply spent critical years of his life. It was this highly personal and emotionally loaded locality that quickly replaced the previous image of the former Soviet Union that spanned 10-time-zones and was always considered the ultimate "homeland" for all Soviet People (Krupnik and Vakhtin 2002: 19).

What is interesting is that this changing self-ascription resulted in the reinforcement of Yupiget's bond with the Russians. Thus, in comparison to 2003, during which the majority of the Yupiget I interviewed proudly marked that they were "first of all Eskimos," while distancing themselves from Russians (often by means of expressing negative attitudes towards the Russian language), in 2005, they would often refer to themselves as being "more Russian" or "more Soviet" than Yupik. It was expressed through following phrases: "We always said the Russians won't leave us." "We are all Soviet." "Of course we are more Russian; we have a history together."

At the same time, the Yupik people in Chukotka became less enthusiastic about their American neighbours. This could be due to negative attitudes between the Yupiget of Chukotka and St. Lawrence Island that have been developing in the recent years (due

18 See www.novayagazeta.ru/data/2004/95/07.html.

19 To follow the editorial policy of the journal Études/Inuit/Studies, in this text I did not use the term "Eskimo" when referring to people. Yet in Russia, the term is still widely used, and was thus used in my survey. 
to unjustified hopes), or their lack of communication and cooperation. The international relationship that was a legacy of the Yupik population throughout the 1990s seems to have become the property of the Russian (and American) majority. Today, the English language is the most important intermediate means between the Americans and the Russians. Consequently, apart from the elderly population that are still fluent in the Yupik language, the majority of the Yupik people in Chukotka prefer to learn English.

As the status and knowledge of the English language in Chukotka and in Russia increases, the Yupik language is no longer needed as a communicative medium. Without a symbolic "need" for the Yupik language, a majority of the Yupiget in Chukotka being in favour of the majority language(s), and without governmental support whatsoever, the motivation and prospect to learn and speak the Yupik language is minimal, if any. Moreover, due to 70 years of Russian dominance in the area, Russian has become the Native language of the population. It is the language of administration, industry, mass media, and education. For the young people in particular, Russian is their mother tongue and most often, the only language known. It is a key instrument for getting a better education, a better job, and a better life.

\section{Conclusion}

The outburst of interest towards the Yupik language in Chukotka in the last decade of the 20th century was related to an increasing sense of ethnic identification among the Yupik population of the Russian Far North. During this time, the Yupik language became the most explicit marker of Yupik identity, an instrument of adaptation in the attempt of a community to adjust to a rapidly changing socio-economic and political environment. As Edwards (1985: 98) writes, if "the essence of group identity is individual identity and the essence of individual identity, ultimately, is survival, personal security and well-being," then, the identity that provides a means of survival will be reinforced. In this situation, language can become the symbol of the struggle for survival and the most explicit marker of identity. Certainly, the discontinuity of old Soviet values on the one hand and restitution of old tradition on the other increased "a need" in the ethnic identity and in Yupik language as marker of that identity, even though the majority of the Yupiget did not speak the Yupik language anymore. A significant factor here, however, was a similarity of Chaplino Yupik with the SLI Yupik language, which allowed the Yupik people to use the language as an important means of communication.

As contact between the Yupik people ceased and Yupik identity became secondary to the newly established localism (alongside the changing economical status of the region), the significance of the Yupik language as a symbol of ethnic identity has ceased and the motivation for learning or speaking that language has became minimal. Identity, however, is a matter of internal as well as external definition (Jenkins 1997: 11). With language being an important principle of ethnocultural differentiation, it is important to keep in mind that there is a big difference in how this marker of identity is used by the people themselves, on the one hand, and by the official authorities and 
researchers, on the other (Golovko et al. 2004: 204). In Russia, the Soviet language ideology played a major role, and placed language as the main criteria for ethnic definition and differentiation, shaping local people's attitudes toward identity, ethnicity, and language. Hence, even today (after more than 15 years after the dissolution of the USSR) the Russian influence in the area is still very strong, and the people's attitudes toward their languages and their identities are very much dominated by the Russian-speaking incomers and the ethnic ideology of the Soviet times.

As it seems, the Yupik language uses that I witnessed in Chukotka in 2003 are the remains of the post-Soviet transition, which allowed the Yupik population to negotiate their identities and transform their Yupik language into the most significant symbolic (as identity marker) and communicative (as intermediate between Yupik people) means. Yet, it was just another stage in an overall process of language shift, which was launched by the Soviet ethnic ideology and which the years of transformation were not able to reverse.

The attitudes and preferences of the Yupiget of Chukotka might shift again in the next few years, especially if the region is taken aback by another economical or political predicament. Therefore, a further analysis of the relation between language and power, and language and economy (in particular, poverty) would be of significance in order to bring us closer to an understanding of the process of language shift. Depending on the change, the Chaplino Yupik language might still have a chance of surviving. A necessary condition for this, I believe, is the preservation of the Yupik language on St. Lawrence Island where people remain loyal to their mother tongue and the latter (though declining rapidly during the past years) is still strong.

\section{References}

AUER, Peter

1990 A discussion paper on code alternation. In European Science Foundation. Network on Code-Switching and Language Contact, Papers for the Workshop on Concepts, Methodology and Data, Basel, 12-13 January 1990: 68-69.

1998 Code-switching in Conversation: Language, Interaction and Identity. London: Routledge.

CLYNE, Michael

2003 Dynamics of Language Contact: English and Immigrant Languages, Cambridge, Cambridge University Press.

COMRIE, Bernard

1981 The Languages of the Soviet Union, Cambridge, Cambridge University Press. 
DIMENT, Galya and Yuri SLEZKINE

1993 Between heaven and hell the myth of Siberia in Russian culture, New York, St. Martin's Press.

EDWARDS, John

1985 Language, Society and Identity, Oxford and New York, Basil Blackwell.

GOLOVKO, Eugenii V., Nikolai B. VAKHTIN and Peter SCHWEITZER

2004 Russkie Starozhily Sibiri: Social'nye $i$ simvolicheskie aspekty samosoznaniya ('Russian Old Believers: Social and Symbolical Aspects of self-awareness'), Moscow, Novoe Izdatelstvo.

GRAY, Patty A.

2005 The Predicament of Chukotka's Indigenous Movement: post-Soviet Activism in the Russian Far North, Cambridge, Cambridge University Press

GROSJEAN, François

1982 Life with Two Languages: An Introduction to Bilingualism, Massachusetts, Harvard University Press.

HOBSBAWM, Eric and Terence RANGER (eds)

1983 The Invention of Tradition, Cambridge, Cambridge University Press.

JENKINS, Richard

1997 Rethinking Ethnicity, London and New Delhi, SAGE Publication.

KERTTULA, ANNA

2000 Antler on the Sea: The Yup'ik and Chukchi of the Russian Far East, Cornell University Press, Ithaca and London

KRAUSS, Michael E.

1980 Alaska Native Languages: Past, present and Future, Fairbanks, University of Alaska, Alaska Native Language Center, ANLC Research Papers, 4.

1997 The Indigenous Languages of the North: A report on Their Present State, in Hiroshi Shoji and Juha Janhunen (eds.), Northern Minority Languages: Problems of Survival, Osaka, Japan, National Museum of Ethnology Senri Ethological Studies, 44: 1-34.

KRUPNIK, Igor I.

1991 Extinction of the Sirenikski Eskimo Language, Études/Inuit/Studies, 15(2): $3-22$

1992 One Nation - One Language: Ideology and Results of Soviet Minority Policies, in Nelson H.H. Graburn and Roy Iutzi-Mitchel (eds.) Language and Educational Policy in the North. Proceedings of the conference, held at 
the University of California, Berkeley, 13-14 March 1992, Berkeley, University of California, Berkeley.

1993 The Chukchi Peninsula and Bering Strait, in Denise Landau, Remote Alaska and the Russian Far East, Copenhagen, University of Copenhagen, Institute for Eskimology: 1-31.

1994 Siberians in Alaska: The Siberian Eskimo Contribution to Alaskan Population recoveries, 1880-1940, Études/Inuit/Studies, 18(1-2): 49-80.

KRUPNIK, Igor I. and Nikolai Vakhtin

2002 In the 'House of Dismay': Knowledge, Culture, and Post-Soviet Politics in Chukotka, 1995-1996, in Erich Kasten (ed.) People and the Land: Pathways to Reform in Post-Soviet Siberia, Berlin, Dietrich Reimer Verlag: 7-43

de REUSE, Willem J.

1994 Siberian Yupik Eskimo, Salt Lake City, University of Utah Press.

SLEZKINE, Yuri

1994 The USSR as a Communal Apartment, or How a Socialist State Promoted Ethnic Particularism, Slavic Review, 53(2): 414-452

ROBERT-LAMBLIN, Joëlle

1993 Socio-demographic situation of the Yuit and Inuit Eskimos and Chukchis of Chukotka, Etudes/Inuit/Studies, 17(2): 73-96.

VAKHTIN, Nikolai B.

1985 Nekotorye osobennosti russko-Aleutskogo dvuyazychiya na Komandorskikh ostrovakh, Voprosy Yazykoznaniya, 5: 35-45.

1992 Native Peoples of the Russian Far North, Copenhagen, University of Copenhagen, Department for Eskimology, Minority Rights Group International Report, 5.

1997 Linguistic Situation in the Russian Far North: Language Loss and Language Transformation, in Osahito Miyaoko and Minoru Oshima (eds), Languages of the North Pacific Rim, Kyoto, Kyoto University, Endangered Languages of the North Pacific Rim, 2: 163-177.

VAKHTIN, Nikolai B. and Evgeniy V. GOLOVKO

1987 The Relationship in the Yupik Eskimo Sub-Group According to Lexicostatistics, Etudes/Inuit/Studies, 11(1): 3-13.

VAKHTIN, Nikolai B. and Igor KRUPNIK

1999 Power, Politics, and Heritage: Undercurrent Transformations in the PostSoviet Arctic - the case of Chukotka, in Frank Sejersen (ed.) Changes in the 
Circumpolar North: Culture, Ethics and Self-determination, Copenhagen, University of Copenhagen, Department for Eskimology, Arctic Social Science Association, 3: 27-42

VAKHTIN, N.B. and N.M YEMELYANOVA

1988 Praktikum po leksike eskimosskogo yazyka (Practice in the Eskimo Language Lexis), Leningrad, Prosveschenie.

WOODBURY, Anthony

1984 Eskimo and Aleut Languages, in David Damas (ed.), Handbook of North American Indians, volume 5, Arctic, Washington, Smithsonian Institution: 49-63. 